\section{Kelompok Rentan dalam Pembangunan Kawasan Kota Bandara di Kulon Progo: Studi Kasus New Yogyakarta International Aiport (NYIA)}

Oleh:

\section{Wahyu Kustiningsih ${ }^{1}$}

\begin{abstract}
Abstrak
Pembangunan bandara merupakan infrastruktur transportasi yang dinilai strategis dalam upaya peningkatan perekonomian lokal. Salah satunya pembangunan bandara baru di Yogyakarta berlokasi di Kulon Progo, yaitu New Yogyakarta International Airport (NYIA). Pembangunan bandara baru yang jauh melebihi target waktu yang ditentukan mengindikasikan adanya problematika sosial khususnya resistensi warga dan isu keberlanjutan aktivitas ekonomi dari warga setempat akibat aglomerasi ekonomi dan privatisasi di area yang terdampak pembangunan kawasan kota bandara. Kritik terhadap pembangunan bandara ini muncul karena adanya privatisasi oleh investor asing dalam pembangunan kawasan bandara atau airport city dianggap mengancam keberlangsungan aktivitas ekonomi kelompok rentan. Kajian ini bertujuan untuk menganalisis mekanisme yang dapat mengakomodasi kepentingan kelompok rentan sehingga dapat berpartisipasi dalam pembangunan di kawasan bandara. Kajian ini menghasilkan tiga rekomendasi, yaitu: keperluan adanya grand design pembangunan bandara yang mempertimbangkan keberlanjutan kelompok rentan, inisiasi program community development guna memberdayakan kelompok rentan, dan perlunya perumusan kebijakan afirmatif bagi kelompok rentan dengan mendasarkan pada asas keadilan sosial.
\end{abstract}

Kata kunci: kelompok rentan, kawasan kota bandara, community development

\footnotetext{
${ }^{1}$ Wahyu Kustiningsih adalah staf pengajar di Departemen Sosiologi, Fisipol, UGM.
}

\begin{abstract}
The development of an airport is considered as a strategic transport infrastructure that will improve local economy. To exemplify such consideration is the development of a new airport in Yogyakarta which is located in Kulon Progo, namely New Yogyakarta International Airport (NYIA). The development of the new airport is experiencing delays and exceeds the previously scheduled. This indicates a social problem which occurs as a response to the development of the airport, such as the resistance of local residents whose daily economic activities are vulnerable due to economies of agglomeration and privatization in the area affected by the development of the new airport city. Major criticism of the development of the airport has emerged since the privatization of the airport is made by foreign investors and may threaten economic sustainability of vulnerable groups. This study aims to analyze a mechanism of accommodating the interests of vulnerable groups, so they are able to participate in economic activities in the area affected by the development of the new airport. The study suggests three recommendations, namely: the necessity of a grand design which recognizes the need of vulnerable groups who are affected by the airport development, the initiation of community development programs in order to empower vulnerable groups, and the need to formulate an affirmative policy for vulnerable groups based on the principles of social justice.
\end{abstract}

Keywords: vulnerable groups, airport city, community development 
Jurnal Pemikiran Sosiologi Volume 4 No. 1, Januari 2017

Wahyu Kustiningsih

Kelompok Rentan dalam Pembangunan Kawasan Kota Bandara di Kulon Progo:

Studi Kasus New Yogyakarta International Airport

\section{Latar Belakang}

Statistik transportasi udara menunjukkan bahwa jumlah penerbangan dan penumpang di Indonesia terus bertambah tiap tahunnya (BPS 2016). Berdasarkan data terakhir, jumlah kedatangan penerbangan dalam negeri (domestic) pada tahun 2014 sebanyak 769.762 pesawat dengan 73.889.533 penumpang. Angka tersebut mengalami kenaikan menjadi 791.783 pesawat dengan 75.593.248 penumpang pada tahun 2015. Kenaikan jumlah penerbangan disebabkan oleh pelbagai faktor, yaitu kondisi geografis Indonesia yang bersifat kepulauan yang berdampak pada ekspansi rute baru, pertumbuhan jumlah penduduk, peningkatan kesejahteraan penduduk, dan kebutuhan waktu tempuh yang semakin singkat. Dalam rangka mendukung pertumbuhan industri penerbangan yang pesat, Kementrian Perhubungan berencana membangun 45 bandara baru dalam kurun waktu 10 tahun hingga tahun 2022 (Bandara Online 2012). Pembangunan tersebut terbagi atas 24 bandara hingga tahun 2017 dan sisanya akan dibangun secara bertahap hingga 2022. Salah satu bandara baru yang akan dibangun pada tahun 2017 ialah New Yogyakarta International Airport atau NYIA di Temon, Kabupaten Kulon Progo, D.I. Yogyakarta.

Pembangunan bandara baru seringkali digaungkan akan memberikan dampak positif terhadap pertumbuhan ekonomi sekitarnya (Knippenberger 2010:214). PT Angkasa Pura I (2014), selaku manajemen NYIA, dalam kegiatan sosialisasi rencana pembangunan NYIA menyatakan bahwa adanya bandara baru akan memberikan kesempatan kerja dan peluang berusaha bagi masyarakat setempat. Namun, perlu diperhatikan bahwa pembangunan bandara baru juga akan menimbulkan konteks kerentanan (vulnerability context). Kerentanan yang muncul dapat berupa guncangan-guncangan (shocks), ketidakpastian, dan kemungkinan terganggunya masa depan penghidupan. Kerentanan ini bisa mengganggu aset-aset penghidupan warga dalam bentuk sumber daya manusia (human capital), sumber daya alam (natural capital), keuangan (financial capital), sosial (social capital), dan infrasruktur (physical capital).

Berdasarkan uraian di atas, tulisan ini fokus pada bagaimana pembangunan infrasturktur berupa bandara berdampak pada peningkatan kualitas hidup dari kelompok rentan. Secara spesifik, tulisan ini membahas bagaimana memberikan ruang bagi kelompok rentan terdampak bandara baru, supaya berpartisipasi dan menikmati pembangunan perkotaan atau kota bandara (airport city). Alur tulisan bermula dari ketidaksesuaian kebijakan pembangunan dari pusat atau nasional dengan kebijakan pembangunan dari lokal atau daerah. Kemudian, tulisan ini akan memaparkan dinamika sosial pembangunan banra baru. 
Jurnal Pemikiran Sosiologi Volume 4 No. 1, Januari 2017

Wahyu Kustiningsih

Kelompok Rentan dalam Pembangunan Kawasan Kota Bandara di Kulon Progo:

Studi Kasus New Yogyakarta International Airport

Terakhir, tulisan ini mengarah pada bagaimana memberi affirmative policies bagi kelompok rentan terdampak bandara.

\section{Metodologi}

Penelitian ini dimulai sejak tahun 2014 ketika awal dilaksanakannya sosialisasi rencana pembangunan New Yogyakarta International Airport atau NYIA. Saat itu, peneliti sebagai bagian dari Tim Peneliti Pusat Studi Pedesaan dan Kawasan (PSPK) UGM yang bermaksud untuk memetakan program community development (comdev) bagi warga di kecamatan Temon Kabupaten Kulon Progo yang terdampak pembangunan bandara baru, khususnya kelompok rentan. Peneliti menghadiri kegiatan sosialisasi yang adakan oleh PT Angkasa Pura di beberapa desa terdampak pembangunan NYIA, antara lain desa Jangkaran, desa Sindutan, desa Palihan, desa Kebonrejo, desa Temon Kulon, dan desa Glagah. Peneliti melakukan pengumpulan data hampir selama 6 (enam) bulan, mulai dari wawancara warga terdampak, hingga melakukan FGD dengan pelbagai stakeholder. Pada tahun 2016, peneliti secara independen berkesempatan untuk kembali ke lapangan tepat saat proses pembebasan tanah untuk bandara baru. Kali ini, peneliti melakukan observasi di beberapa lokasi dan melakukan wawancara dengan beberapa warga terdampak terkait kesiapan mereka dengan akan dimulainya pembangunan bandara baru dan rencana untuk kehidupan mendatang (sustainability).

Secara keseluruhan, pendekatan yang digunakan dalam penelitian ini ialah kualitatif dengan tujuannya untuk menghasilkan deskripsi yang komprehensif dan mendalam terkait dinamika sosial pembangunan bandara baru. Metode penelitian yang digunakan antara lain:

(1) Observasi yang dilakukan secara langsung dengan mengamati kehidupan masyarakat setempat, khususnya warga terdampak pembangunan bandara baru di 6 (enam) desa;

(2) Pengumpulan data sekunder yang dilakukan melalui instansi terkait, media massa, dan pencarian jurnal atau literatur;

(3) Diskusi kelompok terarah atau FGD (Focus Group Discussion) dilakukan dengan melibatkan warga terdampak, tokoh masyarakat, kelompok rentan, dan stakeholder lainnya; dan

(4) Wawancara mendalam (in-depth interview) dilakukan guna menyelami informasi, misalnya dari narasumber FGD atau lainnya. Data hasil wawancara dan FGD berupa transkrip, serta data lainnya, kemudian dikategorisasikan dan dianalisis guna memunculkan temuan-temuan sesuai dengan tujuan penelitian. 
Jurnal Pemikiran Sosiologi Volume 4 No. 1, Januari 2017

Wahyu Kustiningsih

Kelompok Rentan dalam Pembangunan Kawasan Kota Bandara di Kulon Progo:

Studi Kasus New Yogyakarta International Airport

Bandara, Aglomerasi Ekonomi, dan Privatisasi

Infrastruktur memiliki peranan krusial dalam pertumbuhan dan pembangunan suatu negara (Percoco 2010:2427). Indonesia saat ini melakukan pembangunan infrastuktur secara masif. Keterbatasan kemampuan pemerintah untuk mendanai seluruh infrastuktur membuat pemerintah memilih untuk melakukan kerjasama dengan sektor privat. Proyek semacam ini disebut dengan Public Private Partnership. Bappenas (2015) merilis data tentang proyek pembangunan infrastruktur yang siap ditawarkan atau dilelang (ready to offer), yang akan datang (prospective), dan yang berpotensi (potential) dari pelbagai provinsi di Indonesia. Dalam data tersebut, proyek pembangunan NYIA termasuk dalam proyek yang berpotensi dan diperkirakan menghabiskan anggaran sebesar US \$500 juta.

Bandara (airports) merupakan infrastruktur di bidang transportasi yang dianggap strategis. Bandara dianggap berperan signifikan dalam pengembangan ekonomi (Freestone, Williams, and Bowden 2006:491). Bandara sudah sejak lama dipertimbangkan sebagai bagian penting dari pembangunan regional (Percoco 2010:2429). Kehadiran bandara memunculkan pengembangan bisnis nonpenerbangan, seperti: hotel, lokasi-lokasi pusat bisnis, pusat perbelanjaan moderen, outlets makanan cepat saji, dan sebagainya.
Bandara menjadi lokasi yang semakin menarik bagi aktivitas ekonomi dengan aksesibilitas baik di skala internasional, nasional, regional, dan metropolitan (Schaafsma dkk 2008 dalam Freestone dan Wiesel 2014:280).

Pemerintah Daerah (Pemda) Kabupaten Kulon Progo menyambut rencana pembangunan bandara baru di wilayahnya. Mereka optimis bahwa bandara baru akan meningkatkan Pendapatan Asli Daerah (PAD) seperti Kabupaten Sleman lokasi Bandara Adisucipto. PAD yang diharapkan tidak datang langsung dari bandara, namun perusahaan-perusahaan, hotel-hotel, dan lainnya yang bermunculan paska adanya bandara. Keberadaan bandara akan menarik investor baru yang berdampak pada pengembangan wilayah.

Sejak kebangkitan studi tentang determinan aglomerasi ekonomi, bandara dilihat tidak hanya sebagai elemen dari kebijakan pembangunan berdasarkan permintaan (demand), namun juga sebagai ruang interaksi tatap muka dan produktivitas, khususnya dalam industri padat karya, seperti sektor jasa (Percoco 2010:2428). Aglomerasi ekonomi antar kota yang didukung oleh transportasi udara merupakan hal penting (Brueckner 2003:1456). Pelayanan dari perusahaan penerbangan yang buruk dianggap membatasi dan menghalangi pengembangan ekonomi kota. Kapasitas bandara dalam menstimulasi interaksi 
Jurnal Pemikiran Sosiologi Volume 4 No. 1, Januari 2017

Wahyu Kustiningsih

Kelompok Rentan dalam Pembangunan Kawasan Kota Bandara di Kulon Progo:

Studi Kasus New Yogyakarta International Airport

langsung dipengaruhi oleh kualitas perusahaan penerbangan yang diukur dalam bentuk koneksivitas dengan wilayah lain (Brueckner 2003 dalam Percoco 2010:2428).

Lokasi bandara baru di Temon diperkirakan dapat memberikan keuntungan bagi pengembangan ekonomi di kota-kota kecil yang ada di sekitarnya, misalnya Purworejo dan Kutoarjo (Provinsi Jawa Tengah), serta Kabupaten Bantul melalui jalur lingkar selatan Deandles. Selain itu, pembangunan aglomerasi ekonomi akan dilakukan pada kota kecamatan yang ada di sepanjang jalan utama antara Temon hingga Kota Yogyakarta. Perubahan urban landscape membawa evolusi peran bandara dari penyedia infrastruktur (infrastructure providers) menjadi entitas komersil (Comercial entities) (Gerber 2002 dalam Freestone dkk 2006). Hal ini ditambah dengan rencana Kementrian Pekerjaan Umum dan Perumahan yang akan membangun jalur bebas hambatan yang dibuat dekat lokasi bandara baru dan menghubungkan hingga Jawa Tengah. Pembangunan yang terjadi mentransformasikan bandara ke dalam titik aktivitas utama yang berimplikasi terhadap struktur spasial, transportasi, pasar properti komersil, lingkungan dan sistem perencanaan perkotaan.

Ada empat dampak ekonomi dari adanya bandara, yaitu: dampak langsung (direct impact), dampak tidak langsung (indirect impact), dampak stimulan (induced impact), dan dampak katalitik (catalytic impact) (Graham (2003) dan ACI (2004) dalam Percoco 2010:2429). Pertama, dampak langsung, yaitu berupa pekerjaan dan pendapatan yang diperoleh dari konstruksi dan operasional bandara. Dampak ini diperoleh apabila terlibat secara langsung pada dua tahapan tersebut. Proses konstruksi bandara termasuk dalam megaproyek dengan melibatkan jumlah tenaga kerja yang besar. Akan tetapi, proyek tersebut bersifat tender, sehingga warga setempat tidak dengan mudah terlibat dalam tahap konstruksi. Untuk tahap operasional, kebutuhan tenaga kerja di bandara terbagi atas pekerjaan formal (tetap atau kontrak) dan pekerjaan informal (outsourching). Prasyarat pekerja formal tentu lebih tinggi dibandingkan pekerja informal, misalnya level pendidikan setaraf perguruan tinggi. Menurut data profil pendidikan di Temon tahun 2014, rata-rata pendidikan yang ditempuh warga ialah SMA. Kedua, dampak tidak langsung ialah pekerjaan dan pendapatan yang diperoleh dari distribusi pemasok barang dan jasa. Masyarakat memiliki kesempatan dalam kategori ini. Pemda melalui Dinas Perindustrian dan Perdagangan dapat membuat skema kerjasama dengan manajemen bandara dan perusahaanperusahaan distributor guna peningkatan ekonomi melalui supply produk lokal. Ketiga, dampak stimulan merupakan 
Jurnal Pemikiran Sosiologi Volume 4 No. 1, Januari 2017

Wahyu Kustiningsih

Kelompok Rentan dalam Pembangunan Kawasan Kota Bandara di Kulon Progo:

Studi Kasus New Yogyakarta International Airport

pekerjaan dan pendapatan yang diperoleh berdasarkan pengeluaran dari pendapatan yang disebabkan oleh efek langsung maupun tidak langsung. Bagian ini terkait perputaran uang dalam kawasan. Terakhir, dampak katalitik yaitu pekerjaan dan pendapatan yang diperoleh dari peran bandara sebagai pendorong pertumbuhan produktivitas dan sebagai penarik perusahaan-perusahaan baru. Masyarakat bisa jadi tidak bekerja di bandara, namun bekerja pada supporting system dari bandara, misal hotel, perusahaan jasa transportasi, dan lainnya.

Frekuensi pelayanan atas pelbagai tujuan penerbangan merefleksikan jumlah penumpang yang tinggi, memfasilitasi kontak langsung dengan bisnis di kota lain, merangsang kedatangan perusahaan baru di kota tersebut dan menstimulasi pekerja untuk mendirikan usaha (Brueckner 2003:1467). Riset yang dilakukan pada area metropolitan di Amerika oleh Brueckner memperlihatkan bahwa setiap kenaikan 10 persen dari jumlah penumpang pesawat terbang, maka kira-kira ada peningkatan 1 persen pekerja dalam industri yang terkait pelayanan penerbangan. Akan tetapi, hasil riset tersebut mengatakan bahwa kepadatan penerbangan tidak berdampak pada manufaktur. Hal ini menunjukkan bahwa kondisi penerbangan tidak begitu penting bagi perusahaan dibandingkan bagi bisnis terkait pelayanan penerbangan. Kecenderungan tersebut mengeneralisasikan tentang hubungan kausalitas antara pekerja dengan kepadatan lalu lintas penerbangan.

NYIA yang digawangi oleh PT Angkasa Pura I selaku BUMN membentuk perusahaan patungan ataujoint venture bersama dengan investor, yaitu GVK dari India. Perusahaan tersebut merupakan perusahaan pengelola bandara yang mengelola Bandara Mumbai dan Bangalore di India. Pendanaan bandara baru berasal dari joint venture dan sama sekali tidak menggunakan APBN. PT Angkasa Pura I menggunakan dana korporasi dalam membangun bandara baru di Kulon Progo. Di sisi lain, proyek bandara baru ini merupakan megaproyek yang dianggap potensial di Indonesia (Bappenas 2015). Hal ini mengindikasikan bahwa sebenarnya proyek bandara baru ini merupakan proyek pada level nasional dan bersifat sentralistik. Terkait isu desentralisasi, pemerintah daerah dalam hal ini hanya sebagai pelaksana khususnya dalam proses penyediaan lahan.

Kebijakan terkait pembangunan bandara baru sepenuhnya dari pusat. Hal ini diindikasikan sebagai penyebab ketidaklancaran dalam proses pelaksanaan dan terkesan pemerintah daerah tidak siap dalam membangun kawasan yang didukung bandara bertaraf internasional. Ketidaksiapan pemda terpetakan dengan belum adanya grand design atau bahkan master plan kota bandara, dan juga terkait 
Jurnal Pemikiran Sosiologi Volume 4 No. 1, Januari 2017

Wahyu Kustiningsih

Kelompok Rentan dalam Pembangunan Kawasan Kota Bandara di Kulon Progo:

Studi Kasus New Yogyakarta International Airport

pengurusan AMDAL. Kondisi tersebut dinilai cukup krusial dan menyebabkan beberapa hal yang bersifat fundamental, yaitu kekhawatiran munculnya privatisasi dan semakin tersingkirnya kelompok rentan dari pembangunan di kotanya sendiri.

Privatisasi bandara membuat investasi pada bandara baru bergeser ke sektor privat (Freestone and Wiesel 2015:50). Hal ini terjadi seiring mengalirnya privatisasi ekonomi melalui ruang ekonomi pada level sub nasional dan secara efektif membongkar jaringan nasional, kemudian membuka jalur investasi swasta asing dan mempromosikan pembangunan komersial di lokasi-lokasi favorit. Privatisasi bandara terjadi ketika pembangunan hanya berorientasi pada bisnis (Freestone 2011:116). Kritik yang muncul di negara maju ialah bahwa pemerintah cenderung menyetujui rezim bandara yang tidak terintegrasi secara efektif dengan negara dan pembuat kebijakan lokal. Selama ini ada ketegangan antara pengelola bandara, pemerintah, komunitas, dan kepentingan korporasi terkait konstruksi pusat perbelanjaan, blok perkantoran, pabrik, dan pembangunan non-aeronautical, serta proses perencanaan konvensional yang selama ini dikawal oleh negara.
Dinamika Sosial Pembangunan New
Yogyakarta International Airport (NYIA)

Pembangunan NYIA diawali dengan studi kelayakan (feasibility study) pada tahun 2012 yang dilaksanakan oleh Pusat Studi Transportasi dan Logistik (PUSTRAL) UGM, Pusat Studi Ekonomi dan Kebijakan Publik (PSEKP) UGM, serta Landrum \& Brown Worldwide Service. Studi ini dilakukan atas dasar Memorandum of Understanding (MoU) antara PT Angkasa Pura dan Indian Investor GVK pada 25 Januari 2011. MoU lanjutan dilakukan antara PT Angkasa Pura 1 dengan Pemerintah Daerah Istimewa Yogyakarta, khususnya untuk membuat master plan NYIA. Studi ini dilakukan di 7 (tujuh) potensi lokasi pembangunan NYIA, antara lain:

1) Bandara Adisucipto (kabupaten Sleman);

2) Selomartani (kabupaten Sleman);

3) Bandara Gading (kabupaten Gunung Kidul);

4) Gadingharjo (kabupaten Bantul);

5) Bugel (kabupaten Kulon Progo);

6) Temon (kabupaten Kulon Progo); dan

7) Bulak Kayangan (kabupaten Kulon Progo).

Studi kelayakan di atas mempertimbangkan beberapa faktor, antara lain:

1) dampak ekonomi;

2) penilaian finansial; 
Jurnal Pemikiran Sosiologi Volume 4 No. 1, Januari 2017

Wahyu Kustiningsih

Kelompok Rentan dalam Pembangunan Kawasan Kota Bandara di Kulon Progo:

Studi Kasus New Yogyakarta International Airport

3) kelayakan sosial (dampak komunitas, harmoni budaya, lingkungan alam);

4) kelayakan pembangunan regional (kesesuaian dengan perencanaan regional, kesesuaian dengan perencanaan sistem transportasi, kebijakan pengembangan regional, zona bencana, isolasi, dan batas area);

5) kelayakan teknis (daya dukung tanah, kondisi eksisting lahan, kondisi permukaan, jarak dari pusat kota, infrastruktur);

6) kelayakan operasional (kondisi ruang udara, faktor kegunaan, batas ketinggian, visibilitas, jarak dengan bandara terdekat);

7) kelayakan lingkungan (penggunaan tanah, kepemilikan tanah, populasi yang terelokasi, sistem drainase);

8) kelayakan lalulintas udara (potensial penumpang, potensial pesawat terbang);

9) ketersediaan tanah (kebutuhan tanah bandara, ketersediaan lokasi);

10) pembiayaan (CAPEX dan OPEX);

11) pendapatan/ revenue (aeronautical dan non aeronautical revenue).

Berdasarkan faktor tersebut, lokasi yang dianggap paling potensial ialah kecamatan Temon di kabupaten Kulon Progo. New Yogyakarta International Airport (NYIA) akan dibangun secara bertahap. Pembangunan tahap pertama meliputi terminal penumpang seluas 130 ribu meter persegi dengan kapasitas 15 juta penumpang per tahunnya; dan landas pacu sepanjang 3.250 meter dan area parkir pesawat berkapasitas hingga 35 pesawat. Tahap kedua merupakan pengembangan lanjutan terminal penumpang menjadi 195 ribu meter persegi dengan daya tampung hingga 20 juta penumpang pertahunnya, serta landas pacu diperpanjang menjadi 3.600 meter dan pengembangan area parkir pesawat berkapasitas hingga 45 pesawat. Pengembangan ini dilakukan supaya dapat melayani pesawat berbadan besar seperti jenis Boeing 747-400. Pembangunan bandara baru seluas 587 hektar yang sebenarnya sudah dimulai sejak 7 tahun sebelumnya dan ditargetkan akan selesai pada tahun 2019 merupakan respon dari pemerintah daerah setempat dan PT Angkasa Pura I terhadap lonjakan lalu-lintas penerbangan dan alternatif mengatasi keterbatasan pengembangan. Saat ini, bandara eksisting di Yogyakarta ialah Bandara Adisucipto. Bandara ini sedang menghadapi problematika dalam pengembangan lokasi karena keterbatasan lahan, sehingga tidak dapat melakukan pengembangan landasan (runway). Faktor lainnya ialah keberadaan cagar budaya Candi Ratu Boko dan kepadatan rumah penduduk di sekitar lokasi.

Status Bandara Adisucipto sebagai civil enclave airport atau bandara yang berlokasi di fasilitas militer, dalam hal ini ialah 
Jurnal Pemikiran Sosiologi Volume 4 No. 1, Januari 2017

Wahyu Kustiningsih

Kelompok Rentan dalam Pembangunan Kawasan Kota Bandara di Kulon Progo:

Studi Kasus New Yogyakarta International Airport

Markas Besar TNI Angkatan Udara Yogyakarta, mengharuskan berbagi landasan untuk kegiatan operasi militer, pelatihan militer, dan penerbangan sipil. Padahal, kapasitas dari landasan yang ada tidak mencukupi bagi penerbangan sipil. Data dari PT Angkasa Pura 1 (2014) menunjukkan bahwa jumlah penumpang di Bandara Adisucipto pada tahun 2011 sebanyak 4,3 juta penumpang, tahun 2012 sebanyak 4,9 juta penumpang, dan tahun 2013 sebanyak 5,7 juta penumpang per tahun. Jumlah tersebut jauh di atas kapasitas Bandara Adisucipto yang hanya sebesar 1,2 juta penumpang per tahun. Lonjakan penumpang diindikasikan sebagai dampak dari pertumbuhan sektor pariwisata di Yogyakarta dengan salah satu indikatornya ialah jumlah akomodasi, kamar dan tempat tidur hotel yang kian bertambah tiap tahunnya (BPS D.I.Yogyakarta 2016).

Pembangunan bandara baru yang direncanakan mulai konstruksi pada awal tahun 2015 dan mulai beroperasi di tahun 2017 terpaksa mengalami kemunduran dari waktu yang ditentukan. Lamanya waktu yang dibutuhkan dari awal sosialisasi rencana pembangunan bandara hingga dimulainya konstruksi bandara di awal 2017 menggambarkan ada persoalan terkait resistensi dari masyarakat setempat, khususnya dalam mempertahankan tanah mereka, baik berstatus hak milik maupun sewa. Salah satu pihak yang cukup keras menentang pembangunan bandara ialah Wahana Tri Tunggal atau akrab disebut dengan WTT.

Berdasarkan hasil observasi dan wawancara, resistensi yang muncul sejak awal sosialisasi, bahkan hingga saat ini di tahap awal konstruksi bandara baru, terkait dengan ancaman terhadap mata pencaharian sebagai sumber penghidupan masyarakat. Lokasi bandara baru, yaitu kecamatan Temon, merupakan kawasan perdesaan yang mayoritas penduduknya mengandalkan sektor pertanian sebagai mata pencaharian mereka. Petani di Temon terbagi menjadi petani pemilik lahan, petani penggarap, dan keduanya. Petani penggarap mengacu pada petani yang tidak memiliki lahan dan umumnya mengerjakan lahan milik orang lain atau menyewa tanah. Tanah yang umum disewa oleh petani di wilayah Temon ialah Sultan Ground (SG) dan Paku Alam Ground (PAG).

Adanya bandara baru mengancam petani penggarap karena mereka tidak mendapatkan kompensasi atas kehilangan mata pencaharian utama karena lahan garapan mereka digunakan untuk pembangunan bandara. Di sisi lain, resistensi juga muncul cukup kuat dari petani pemilik lahan yang terdampak bandara pada awal proses. Mereka merasa khawatir dengan masa depannya apabila lahan miliknya yang selama ini menjadi sumber penghidupan tidak ada lagi. Kekhawatiran yang muncul juga terkait 
Jurnal Pemikiran Sosiologi Volume 4 No. 1, Januari 2017

Wahyu Kustiningsih

Kelompok Rentan dalam Pembangunan Kawasan Kota Bandara di Kulon Progo:

Studi Kasus New Yogyakarta International Airport

dengan nilai ganti rugi atas tanah dan bangunan yang dikhawatirkan akan bernilai rendah dan tidak sesuai harapan.

Pada September 2016, PT Angkasa Pura I mulai menyiapkan ganti rugi lahan terdampak bandara sebesar \pm Rp4,146 triliun. Menurut hasil wawancara, masyarakat terdampak mengaku jika ganti rugi yang diterimanya ternyata lebih tinggi dibandingkan dengan bayangan sebelumnya. Penilaian atas tanah, bangunan dan isinya pun bervariasi. Partisipasi gerakan perlawanan lokal pun mulai menyusut secara kuantitas. Proses ganti rugi ini pun mengalami kendala yaitu dana turun secara bertahap di awal sebesar Rp2 triliun.

Besarnya dana ganti rugi yang diterima oleh warga pemilik tanah terdampak membuat mereka berbondong-bondong membeli kendaraan (mobil) baru dan mendaftarkan diri mereka beserta keluarga untuk beribadah umroh atau haji. Lain halnya dengan petani penggarap yang hingga kini masih mengharapkan dana kompensasi atas tergusurnya mata pencaharian mereka. Petani penggarap menjadi bagian dari kelompok rentan karena tidak memiliki aset tanah dan lahan mata pencahariannya terampas.

Di sisi lain, adanya kepastian ganti rugi bagi masyarakat terdampak membuat pemerintah merencanakan desain pariwisata lokal di kawasan bukit Menoreh. Selain itu, pemerintah kabupaten setempat mulai menyiapkan pendampingan bagi warga terdampak bandara. Akan tetapi, rencana relokasi bagi warga terdampak belum tuntas bahkan hingga tahap ganti rugi atas tanah milik warga. Ada sebanyak 518 keluarga di Temon yang memilih untuk direlokasi oleh pemerintah daerah setempat. Pengamatan lapangan yang dilakukan selama ini belum menemukan adanya perencanaan sosial yang matang dalam mengantisipasi persoalan sosial yang cenderung akan muncul seiring transformasi Temon dari perdesaan (rural) menjadi perkotaan (urban). Perencanaan pembangunan masih fokus pada infrastruktur, misalnya hotel, lokasi wisata, jalur transportasi darat sebagai penghubung kota Yogyakarta dengan Temon, dan sebagainya. Pada tahun 2016, Pemda DIY melakukan tinjauan kembali terhadap Perda Nomor 2 Tanuh 2010 tentang Rencana Tata Ruang Wilayah (RTRW) DIY dan kemudian membuat Raperda RTRW yang mengakomodasi pembangunan bandara baru serta memasukkan kawasan keistimewaan sesuai dengan UUK DIY. Raperda RTWR DIY yang baru ini sebagai bentuk respon pemerintah yang selama ini menuai kritik karena pembangunan bandara baru dianggap menyalahi RTRW DIY. Hal ini berdampak pada penetapan poros Temon-Yogyakarta sebagai tumpuan pembangunan transportasi di DIY. 
Jurnal Pemikiran Sosiologi Volume 4 No. 1, Januari 2017

Wahyu Kustiningsih

Kelompok Rentan dalam Pembangunan Kawasan Kota Bandara di Kulon Progo:

Studi Kasus New Yogyakarta International Airport

Perhatian pemerintah daerah yang kemudian berfokus pada pembangunan jalur transportasi penghubung antara bandara baru dengan Kota Yogyakarta memunculkan pertanyaan terkait relasi antara RTRW Provinsi DIY dengan RTRW kabupaten Kulon Progo. Ada hubungan yang hilang antara bandara dengan perencanaan kota yang disebabkan oleh perbedaan yuridiksi sektoral dimana melihat bandara sebagai infrastruktur transportasi semata dan adanya perbedaan skala dari level perencanaan dari nasional ke daerah kemudian ke lokal yang mendevaluasi skala regional secara inheren (Knippenberger, 2010:212). Bandara baru diperkirakan akan membentuk kawasan kota bandara (airport city), artinya akan ada pertumbuhan kota-kota di sekitar bandara. Kasarda's (2000) dalam Freestone dkk. (2006) menyebutnya sebagai aerotropolis yang mengacu pada kota-kota yang muncul di sekitar bandara. Pembentukan kota bandara ini perlu direncanakan sebaikbaiknya dengan mempertimbangkan tidak hanya aspek ekonomi, melainkan juga sosial-budaya, serta melibatkan komunitaskomunitas lokal, sehingga meminimalisir bias pembangunan terhadap kelompok rentan.

Sieverts menyatakan bahwa perubahan bandara di masa depan tidak terprediksi secara pasti. Kondisi ini seharusnya memotivasi perencana tata ruang untuk memahami bandara sebagai bagian terintegrasi dari perkotaan dan masyarakatnya, sehingga membuat bandara tetap berpotensi dan dapat digunakan, bahkan jika fungsi infrastruktur bandara telah berkurang dalam (Sieverts, 2003 dalam Knippenberger.ed., 2010:212). Perencanaan kota harus memainkan peran kunci dalam pertumbuhan lebih dan kritis terhadap isu keberlanjutan, terutama karena dampak bandara hingga di luar batas teritorialnya (Freestone, 2009:172). Oleh karenanya, baik pemerintah pusat maupun daerah perlu secara bersama-sama untuk membuat grand design kota bandara yang bersifat terpadu antar tingkat (nasional-provinsi-kabupaten-lokal) dan antar dimensi (sosial-budaya-ekonomi).

\section{Kelompok Rentan: Yang Tersingkir dari Pembangunan Bandara}

Umumnya, literatur mengatakan bahwa jasa penerbangan berdampak positif pada pembangunan regional, meski ada juga literatur yang mengatakan bahwa dampak positifnya hanya pada ekonomi saja (Bilotkach 2015:1579). Ada beberapa studi yang berusaha untuk mengevaluasi dampak dari pengeluaran publik guna pembangunan infrastruktur, khususnya bandara (Perotti 2004 dalam Percoco 2010:2427). Mereka menemukan bukti bahwa investasi publik tidak memiliki dampak pada pertumbuhan di negaranegara industri. Berdasarkan data dari 75 
Jurnal Pemikiran Sosiologi Volume 4 No. 1, Januari 2017

Wahyu Kustiningsih

Kelompok Rentan dalam Pembangunan Kawasan Kota Bandara di Kulon Progo:

Studi Kasus New Yogyakarta International Airport

area metropolitan di US, ditemukan bahwa

tidak ada relasi antara lalu lintas penerbangan dengan keterserapan pekerja lokal (local employment) dalam industri penerbangan (Brueckner 1982 dalam Percoco 2010:2429).

Pembangunan NYIA yang menggandeng sektor privat asing dan dengan dana di luar APBN mengisyaratkan indikasi kemunculan privatisasi yang dianggap sebagai bagian dari rezimentasi neoliberalisme. Janji manis pertumbuhan ekonomi dari Investasi Asing Langsung (Foreign Direct Investement) membuat pemerintah membuka pasar (market). Regulasi-regulasi pro rakyat pun diruntuhkan dan kemudian diganti dengan regulasi-regulasi yang ramah pasar (market friendly). Perekonomian rakyat menjadi terancam. Pasar memiliki kuasa yang sangat besar, bahkan terhadap negara, aparatus negara, dan masyarakat sipil.

Pertanyaan kemudian ialah terkait kesejahteraan warga. Sistem perekonomian yang karut-marut akan memposisikan sekelompok besar warga di lapis terbawah-kaum petani, nelayan, buruh, para pekerja sektor informal, dan lainnyasebagai tumbal "pasca-pembangunanisme" atau "neoliberalisme". Liberalisasi pasar yang terjadi justeru bukan menyejahterakan warga, melainkan menciptakan krisis berupa polarisasi sosial (Graham and Aurigi 1997:19).

Warga lapisan bawah atau identik dengan sebutan kelompok rentan dapat digolongkan menurut status sosial ekonomi, gender, usia, kesehatan, pengangguran, dan lainnya (Gidley et al. 2010:2). Berdasarkan kondisi di Temon, kelompok rentan yang berhasil terpetakan meliputi: warga miskin; petani dan nelayan; balita, anak dan lansia; perempuan; dan difabel. Warga miskin merupakan warga yang tidak memiliki aset dan/atau memiliki aset dalam jumlah sedikit dan terbatas. Warga dalam kategori ini tidak mendapatkan dan/atau mendapatkan dalam jumlah kecil ganti rugi pembebasan tanah. Golongan petani dan nelayan merupakan warga yang mata pencahariannya hilang. Pengalaman menjadi petani atau nelayan bisa jadi selama usia mereka. Proses adaptasi apabila mereka harus berganti mata pencaharian juga bukan merupakan perkara yang mudah dan instan. Di sisi lain, kebutuhan pasar kerja mensyaratkan kualifikasi yang cukup tinggi. Kemudian, kategori balita, anak dan lansia membutuhkan perhatian ekstra terkait jaminan kesehatan. Pada kawasan perkotaan, biaya-biaya kebutuhan dasar menjadi lebih mahal. Selain itu, degradasi kualitas lingkungan berasosiasi dengan resiko penyakit. Khusus untuk anak, pemerintah daerah seyogyanya menjamin keberlanjutan pendidikan mereka, sehingga ke depannya nanti dapat dipertimbangkan sebagai bagian dari aktor dalam perekonomian lokal. Kelompok perempuan dan kelompok difabel menjadi bagian dari kelompok rentan karena persoalan akses, 
Jurnal Pemikiran Sosiologi Volume 4 No. 1, Januari 2017

Wahyu Kustiningsih

Kelompok Rentan dalam Pembangunan Kawasan Kota Bandara di Kulon Progo:

Studi Kasus New Yogyakarta International Airport

khususnya akses ekonomi di ranah publik. Penguatan kapasitas bagi keduanya sangat diperlukan supaya mereka juga merasakan manfaat pembangunan lokal daerahnya.

Respon pemerintah terhadap problematika kelompok rentan haruslah berbentuk kebijakan legal. Kebijakan tersebut mengakomodir pelbagai kepentingan dari komunitas-komunitas lokal dan juga kelompok rentan. Kebijakan tersebut tidak berlaku sama antara satu sama lain. Hal yang terpenting ialah bahwa kebijakan tersebut harus memperhatikan aspek keadilan sosial.

\section{Kesimpulan}

Kecenderungan yang muncul di negaranegara maju seperti Australia dan USA, kota di sekitar bandara mengalami privatisasi. Pembangunan kota yang dikendalikan oleh 'city marketing' dan privatisasi cenderung secara pasti mentransformasikan ruang menjadi komoditas. Kota mengalami dilema tata ruang. Ini memberikan dampak cukup besar terhadap kota yang awalnya dimiliki oleh masyarakat, kemudian beralih sebagai penghasil uang dengan mempromosikan citra (image) kota kepada konsumen dari luar. Keberadaan turis menjadi sesuatu yang lebih penting, hingga kemudian kita sebagai masyarakat asli berubah menjadi turis di kota sendiri. Hingga akhirnya kota mengalami krisis.
Pembangunan ekonomi tidak hanya dipandang sebagai proses ekonomi semata, melainkan juga merupakan bentuk dari perubahan sosial dan kebudayan yang ada dalam masyarakat (Soedjatmoko 1995:21). Hal ini seharusnya menjadi dasar dalam pengambilan kebijakan yang menyangkut hajat hidup orang banyak. Pembangunan bandara baru yang menjanjikan keuntungan finansial, juga harus dilihat pada aspek terjadinya perubahan sosial dan budaya dari masyarakatnya. Pembangunan ekonomi yang identik dengan pembangunan infrastruktur yang masif harus senantiasa memperhatikan kualitas manusianya dalam kerangka ekualitas (equality) dan bersifat inklusif (inclusive), khususnya bagi kelompok rentan.

Ada beberapa hal yang dapat mendukung terwujudnya hal tersebut. Pertama, Pemda membuat grand design khusus kota bandara (airport city) yang mengakomodasi kelompok rentan. Untuk konteks di Temon sebagai area pembangunan bandara baru, Pemerintah Daerah Kulon Progo harus memiliki grand design pengembangan kota bandara (airport city) yang bersifat jangka panjang (long term) dan mengakomodasi kepentingan kelompok rentan yang kemungkinan besar paling tersisih apabila kawasan tersebut dikuasai oleh pasar (market). Salah satu langkah untuk menguatkan partisipasi kelompok rentan dalam pembangunan kota dan meningkatkan kesejahteraan hidup mereka 
Jurnal Pemikiran Sosiologi Volume 4 No. 1, Januari 2017

Wahyu Kustiningsih

Kelompok Rentan dalam Pembangunan Kawasan Kota Bandara di Kulon Progo:

Studi Kasus New Yogyakarta International Airport

ialah melalui program community development (comdev) dengan pendekatan people-centered development. Pendekatan ini menekankan pada partisipasi seluruh masyarakat dan stakeholder melalui charity, empowerment, dan building capacity. Kedua, Pemda dan perusahaan yang beroperasi di bandara baru wajib untuk menginisiasi program community development bagi kelompok rentan. Program comdev merupakan bagian dari tanggungjawab sosial perusahaan atau dalam hal ini PT Angkasa Pura I selaku manajemen operasional bandara NYIA, dan perusahaan lain yang ada di kawasan kota bandara, dan pemerintah daerah sebagai fasilitator. Desain program comdev bukanlah semata economic cost tetapi lebih merupakan social investment, yakni suatu bentuk investasi yang hasil dan manfaatnya bagi perusahaan tidak akan diperoleh dalam waktu cepat, melainkan dinikmati dalam jangka panjang. Pemerintah Daerah berkewajiban untuk mendorong adanya program comdev ini, sehingga secara luas nantinya akan berdampak pada kemajuan perekonomian daerah. Ketiga, Pemda diharapkan untuk kebijakan afirmatif bagi kelompok rentan yang mengutamakan asas keadilan sosial (Sen 2009). Dalam sebuah kota yang sedang mengalami krisis, mulai dari adanya privatisasi hingga komodifikasi pelbagai tujuan, maka tumbuh polarisasi sosial (Social Polarization) yang berdampak pada munculnya segmentasi dan pemisahan

atas zona-zona sosial, serta kecenderungan meningkatnya ketidaksetaraan ekonomi secara internal (internal economic inequality) (Graham and Aurigi 1997:19). Sebagai langkah antisipasi, maka pemerintah seyogyanya membuat kebijakan yang mengutamakan kesejahteraan masyarakatnya dan mengevaluasi kebijakan tersebut secara eksplisit dalam bentuk kebijakan yang sesuai preferensi dan kepentingan dari pelbagai macam komunitas (Phillips 1957 dalam Chossudovsky dan Sellekaerts 1974). Ketiga rekomendasi inilah yang menurut hemat penulis dapat menjadi mekanisme alternatif dalam mengakomodasi kepentingan kelompok rentan khususnya warga yang terdampak oleh pembangunan bandara baru di Kulon Progo Yogyakarta.

\section{Daftar Pustaka}

Bilotkach, Volodymyr. 2015. "Are Airports Engines of Economic Development? A Dynamic Panel Data Approach." Urban Studies 52(9):1577-93.

Brueckner, Jan K. 2003. "Airline Traffic and Urban Economic Development." Urban Studies (Routledge) 40(8):1455.

Chossudovsky, Michel and Willy Sellekaerts. 1974. "A Comparison of Optimal and Actual Policies for High Employment and Price Stability under External Inflationary Conditions: The Canadian Experiences." Southern Economic Journal (pre-1986) 41(2):206.

Freestone, Robert. 2009. "Planning, Sustainability and Airport-Led 
Jurnal Pemikiran Sosiologi Volume 4 No. 1, Januari 2017

Wahyu Kustiningsih

Kelompok Rentan dalam Pembangunan Kawasan Kota Bandara di Kulon Progo:

Studi Kasus New Yogyakarta International Airport

Urban Development." International Planning Studies 14(2):161-76.

Freestone, Robert. 2011. "Managing Neoliberal Urban Spaces: Commercial Property Development at Australian Airports." Geographical Research 49(2):11531.

Freestone, Robert and Ilan Wiesel. 2014. "The Making of an Australian 'Airport City'." Geographical Research 52(3):280-95.

Freestone, Robert and Ilan Wiesel. 2015. "Privatisation, Property and Planning: The Remaking of Canberra Airport." Policy Studies 36(1):3554.

Freestone, Robert, Peter Williams, and Aaron Bowden. 2006. "Fly Buy Cities: Some Planning Aspects of Airport Privatisation in Australia." Urban Policy and Research 24(4):491-508.

Gidley, J. M., G. P. Hampson, L. Wheeler, and E. Bereded-Samuel. 2010. "Social Inclusion: COntext, Theory and Practise." The Asutralasian Journal of University-Community Enggagement 5:6-13.

Graham, Stephen and Alessandro Aurigi. 1997. "Virtual Cities, Social Polarization, and the Crisis in Urban Public Space." Journal of Urban Technology 4(1):19-52.

Knippenberger, Ute. 2010. "From Airport City to Airport Region? The 1st International Colloquium on Airports and Spatial Development, Karlsruhe, 2009." The Town Planning Review 81(2):209-15.

Percoco, Marco. 2010. "Airport Activity and Local Development: Evidence from Italy." Urban Studies 47(11):242743.
Sen, Amartya. 2009. The Idea of Justice. Massachusetts: The Belknap Press of Harvard University Press.

Soedjatmoko. 1995. Dimensi Manusia Dalam Pembangunan. Jakarta: LP3ES.

Sumber Internet:

Bandara Online. 2012. "Pemerintah Akan Bangun 45 Bandara Baru Sampai 2022 | Bandar Udara Online." Diakses 11 Maret 2017 melalui http://bandaraonline.com/airport/ pemerintah-akan-bangun-45bandara-baru-sampai-2022

Bappenas. 2015. Publick Privat Partnership: Infrastructure Projetcs Plan in Indonesia 2015. Jakarta. Diakses 11 Maret 2017 melalui http://pkps.bappenas.go.id/attachm ents/article/1302/PPP\%20Book\%2 02015.pdf

BPS. 2016. Statistik Transportasi Udara Tahun 2015. Jakarta: Badan Pusat Statistik. Diakses melalui https://www.bps.go.id/website/pdf _publikasi/Statistik-TransportasiUdara-2015.pdf

BPS D.I.Yogyakarta. 2016. "Jumlah Akomodasi, Kamar Dan Tempat Tidur Hotel Menurut Kabupaten/Kota Di D.I. Yogyakarta, 2006 - 2015." Diakses melalui https://yogyakarta.bps.go.id/linkTa belStatis/view/id/41). 